\title{
The relevance of efficiency market theory to changes in valuation in food and beverages companies listed on the Indonesia stock exchange
}

\author{
P.A. Sebastian, D.P. Abdulrachman \& N.S. Hendriyeni \\ PPM School of Management, Indonesia
}

\begin{abstract}
This study aims to find out the application of the efficiency theory to changes in valuation in food and beverages (F\&B) companies listed on the Indonesia Stock Exchange in 2017-2019. The efficiency theory states that changes in stock prices are influenced by changes in the fundamental factors of the company. Changes in stock prices that are contrary to fundamental changes indicate an inefficient market. The results of this study can assist investors in making investment decisions. This study gives investors a model that they can use in making investment decisions using company fundamental data with indicators such as price to selling ratio, price to earnings ratio, and price to book value ratio. The ratios were obtained from the 2017-2019 quarterly financial reports. The market efficiency data on stock prices were data on the day the financial statements were issued $(t)$, the day before the financial statements were issued $(t-1)$, and one day after the financial statements were issued $(t+1)$. Then, changes in stock prices were compared with changes in the fundamental value of the company's financial statements to obtain the market efficiency value for every F\&B company during the 2017-2019 time period. This study obtained the efficiency level and company valuation in three stages: first, the calculation of the company's fundamental figures and their quarterly development; second, the calculation of the share movement according to the financial statement publication date; and third, an analysis of share movement relevance to the company's fundamentals to obtain the market efficiency value of each company. Keywords: price to selling ratio, price to earnings ratio, price to book value ratio, financial statement, market efficiency, Indonesia Stock Exchange
\end{abstract}

\section{INTRODUCTION}

\subsection{Research background}

The food and beverages (F\&B) industry is growing rapidly in Indonesia, which has the fourth largest population in the world. Thus, the consumer's need for F\&B products is a profitable potential for investment. In the past 20 years, many multinational companies have conducted foreign direct investment (FDI) by establishing large factories, such as Unilever, Heinz, Frisian Flag, Perfetti Van Melle, Mondelez, Coca Cola Amatil, Danone, and Nestle.

This level of investment interest in the Indonesian fast moving consumer goods (FMCG) sector motivates this study on the investors' basis in choosing the best FMCG companies listed on the Indonesia Stock Exchange (IDX) in the 2017-2019 period.

The investors' decision-making methods such as using the market efficiency theory for investing in FMCG companies, as reported in this study, can be used by local investors as the basis for investment. Based on Kustodian Sentral Efek Indonesia (KSEI/Indonesia Central Securities Depository) IDX data, the number of investors who had customer fund accounts and were able to conduct stock transactions at the end of December 2019 was 2,478,243 SIDs (single investor identification), which increased 53.04\% from 2018; it was only 1,619,372 then. Among them, 1,768,485 SIDs were mutual fund customers. 
This sizeable increase was dominated by young people, as shown by KSEI IDX data; $44.62 \%$ were aged $21-30$. They were mostly $(59.41 \%)$ males working in private companies $(53.69 \%)$ and having undergraduate education (48.23\%). The 53.04\% increase from 2018 indicates that there is great potential for the younger generation to invest.

Novice investors can make mistakes because they do not understand companies' fundamental factors and they lack the ability to analyze which stocks have good potential and understand the methods commonly used in making investment decisions coupled with risk analysis in investing before making decisions in buying shares on the IDX. This problem became the background of this study.

\subsection{Research problem}

Based on the background, the formulated research problems are as follows:

a. Is the market efficiency theory relevant to stock price changes in F\&B companies on IDX?

b. Does the change in the valuation of $F \& B$ companies affect market efficiency?

c. Do F\&B companies listed on IDX have good market returns and safe risk value?

\subsection{Research objectives}

This study aims to:

a. Determine the relevance of the market efficiency theory to changes in stock prices in $\mathrm{F} \& \mathrm{~B}$ companies listed on IDX.

b. Determine the effect of changes in valuation on market efficiency in F\&B companies listed on IDX.

c. Determine the level of return and risk on investment in F\&B companies listed on IDX.

\subsection{Research object}

This study examined 17 public companies engaged in the F\&B sector listed on IDX by calculating the companies' fundamental and technical values based on financial statements and changes in stock prices in 2017-2019.

\subsection{Research significance}

This study provides a method for making a purchase decision of an F\&B company stock listed on IDX, thereby reducing the risk of investment loss.

\section{THEORETICAL REVIEW AND HYPOTHESIS}

\subsection{Market efficiency theory}

There are four definitions of efficient capital markets. The first definition is based on the intrinsic value of securities. The efficiency measure is seen from the extent to which security prices deviate from their intrinsic value (Beaver, 1989). Thus, an efficient market can be defined as a market where the values of securities do not deviate from their intrinsic value.

The second definition is based on the accuracy of security prices. Fama (1970) defined that a capital market is efficient when the prices of securities accurately reflect the existing information.

The third definition is based on the distribution of information. Beaver (1989) stated that the market is efficient only if the prices of securities act as if everyone observes the information system. This definition implies that if everyone observes one information system, then everyone is considered to have the same information. Thus, weak and semi-strong efficiency always occurs because 
it is assumed that the information has been distributed and made available to the public. However, Beaver also argued that there is a cost to obtaining this information. Therefore, the information disseminated may only be accepted by some investors and the market becomes inefficient.

The fourth definition is based on dynamic processes (Jones, 1995). This definition considers the asymmetric distribution of information and describes how prices will adjust because of the asymmetric information. The market is said to be efficient if the information dissemination is prompt, so that the information becomes symmetrical, that is, everyone has this information.

\subsection{Multiple valuation}

Multiple Valuation is a valuation measurement based on the sales value (price to selling ratio), net income value (price to earnings ratio), and equity value (price to book ratio) within a certain period (Damodaran, 2012). It tends to measure only the company value historically. A low ratio value means that the possibility of development still exists. However, it cannot estimate the growth of the company.

\section{RESEARCH METHOD}

\subsection{Research type, data source and sample collection method}

This is a basic study, for which the data were collected using a quantitative approach based on secondary data of stock prices from 17 F\&B companies listed on IDX in 2017-2019. In this study, the market efficiency and company valuation were tested and recommendations for investors were given. The data were taken from 17 F\&B companies listed on IDX in the 2017-2019 period. Data were collected using a sampling frame method that was conducted on 17 companies in the $F \& B$ sector listed on IDX in 2017-2019, and the samples were compared to financial reports issued in certain periods by companies or data on IDX.

\subsection{Regression test}

Multiple regression analysis was employed in this study. Multiple regression analysis is a statistical technique using parameter coefficients to determine the influence of the independent variable on the dependent variable. Hypothesis testing, both partially and simultaneously, was carried out after the regression model was free from violations of classical assumptions. The aim was that the results can be interpreted appropriately and efficiently. The regression equation is as follows (Weston \& Copeland, 1992):

$$
\text { Stock Price Change }(\mathrm{Y})=\boldsymbol{\alpha} 1+\boldsymbol{\alpha} 2 \mathrm{PBVR}+\boldsymbol{\alpha} 3 \mathrm{PER}+\boldsymbol{\alpha} 4 \mathrm{PSR}+\mathrm{e}
$$

$$
\begin{array}{ll}
\text { where } & \\
\mathrm{Y} & =\text { stock price change } \\
\alpha 1 & =\text { constant } \\
\alpha 2,3, \boldsymbol{\alpha} 4 & =\text { estimation coefficient of PBV, PER, and PSR } \\
\mathrm{PBVR} & =\text { price to book value ratio/stock price } \\
\mathrm{PER} & =\text { price to earnings ratio/stock price } \\
\mathrm{PSR} & =\text { price to sales ratio/stock price } \\
\mathrm{e} & =\text { error }
\end{array}
$$

\section{RESULTS AND DISCUSSION}

The regression test analyzed the changes in stock prices in 17 consumer goods companies listed on IDX in 2017-2019 based on the stock change data influenced by the PBVR, PER, and PSR in each quarter. 
The regression analysis results employed a maximum error tolerance of $5 \%$, showing that the effect of change in stock prices on the changes in the companies' fundamental ratio was significant in PBVR, PSR, and PER. The adjusted R square value ranged from 0.75 to 0.87 , which indicates that this value is valid to be presented because it is above 0.5 .

It was also found that the PBVR and PSR coefficient values were below 0.01 . This finding indicated that the values had a significant effect on stock price changes. Meanwhile, it was found that stock value change did not have any influence due to its PER significance above 0.01 .

The results of the normality test on all 204 data revealed that the results were normally distributed because the probability was above 0.05 . Therefore, the data can be used in regression calculations.

The probability level of the data significance was above the $5 \%$ confidence level. Therefore, it can be concluded that the regression model did not show heteroscedasticity.

The multicollinearity test analyzed the correlation matrix of independent variables. A high correlation (generally $>0.90$ ) found between variables indicates multicollinearity in the data of stock price changes during $\mathrm{H} 0, \mathrm{H}-1$, and $\mathrm{H}+1$.

\section{CONCLUSIONS AND RECOMMENDATIONS}

This study concludes that changes in PER did not have a significant effect on changes in stock prices. Instead, changes in PER occasionally affected stock prices in the opposite direction. Meanwhile, changes in PSR had a significant effect on changes in stock prices. It was also found that the changes in PBVR had a strong influence on stock price, as the increase of PBVR will increase stock prices and vice versa.

The normality, heteroscedasticity, and multicollinearity tests showed that the data were normally distributed, homogeneous, and linear, except for PER data whose values tended to be different from changes in PBVR and PSR values. From the findings, it can be concluded that to investigate the effect of market efficiency changes on the companies' fundamental ratios, PBVR is an important parameter. Therefore, investors must look at PBVR before purchasing stock rather than considering the net profit value because the changes tend to be inconsistent.

Further studies on the effect of fundamental ratios on market efficiency can be done to test companies in sectors other than consumer goods listed on IDX. Moreover, this study can be developed by adding other factors that are assumed to influence stock price changes such as free cash flow to equity (FCFE), free cash flow to firm (FCFF), debt to equity ratio (DER), and other supporting factors for making investment decisions.

\section{REFERENCES}

Beaver, W.H. 1998. Financial Reporting: An Accounting Revolution. Third Edition. Prentice Hall International, Inc.

Damodaran, Aswath. 2012. Investment Valuation: Tools and Techniques for Determining The Value of Any Asset 3rd Edition, John Wiley \& Sons, Inc, New Jersey USA.

Fama, E.F. 1970. Efficient Capital Markets: A Review of Theory and Empirical Work. Journal of Finance. Vol. 25. 383-417.

Jones, P. 1996. Investments Analysis And Management, Fifth Edition. John Wiley \& Sons, Inc.. The United States of America.

Weston \& Copeland. 1995. Managerial Finance 9th ed., The Dryden Press, 1992. Terjemahan A. Jaka Wasana dan Kibrandoko, Manajemen Keuangan, Jakarta: Binarupa Aksara. 